\title{
The Full Remarks on Advocacy of Lord Brougham and Lord Chief Justice Cock- burn at the Dinner to M. Berryer on November 8, $1864^{1}$
}

The remarks on advocacy made by Lord Brougham and by Lord Chief Justice Cockburn at a dinner given November 8, 1864, "in the Ancient Hall of the Middle Temple" by the Bar of England to the French advocate and statesman, M. Berryer, have such recurrent interest that it would seem to be worth while to reprint them as found in what may be the only existing copy of what purports to be a verbatim report. That copy was presented to the Middle Temple Library on October 18, 1899, by Mr. C. Henderson Scott, who had reported the dinner for the London Post. It is a pamphlet printed in 1865, entitled "Speeches Delivered at the Dinner Given by the Bar of England to M. Berryer, November 8, 1864." The explanation of the printing of the pamphlet is found in Mr. Scott's Memorandum of October 18, 1899 which has been bound with the Middle Temple Library pamphlets. It is that "A few days after the Dinner, Mr. Charles Pollock [who was stated by Mr. Scott to have been 'Honorary Secretary' of the Committee formed to give the Dinner, and 'afterwards a Baron of the Exchequer'] wished me to give the Committee a fuller report of the speeches than appeared in the newspapers, to keep as a record. I consented and was able at my leisure to produce a longer and more careful report than I could do after midnight on the occasion of the Dinner, for the Morning Post. The result was the publication of this pamphlet, which I recently found among my papers. It was only printed for circulation amongst a few persons." He further states that the footnote to Chief Justice Cockburn's speech was added by Mr. Pollock.

The Attorney General, Sir Roundell Palmer, afterwards Lord Chancellor Selborne, presided at the dimner and introduced the speakers. Omitting purely formal parts, the speeches of Lord Brougham and Chief Justice Cockburn on advocacy in full were as follows:

LoRD Brougran: "On the present occasion our attention is called to the French Bar, and more especially to that illustrious man who sits near me, M. Berryer. To whom shall I compare this great advocate? Not certainly to any of the advocates of ancient and classic times, but to one far superior to them all-to our own Erskine, the greatest advocate,

1 This paper embodies a letter to the Editor from Professor Costigan, Emanuel S. Heller Professor of Law, School of Jurisprudence, University of California, who is now on sabbatical leave of absence. 
perhaps, the world ever saw, and I put M. Berryer on a level with him. I have paid attention to the career of both the one and the other, and I find that Lord Erskine and M. Berryer possessed that great faculty of conducting cases with perfect skill and matchless eloquence, and they had both in perfection and in equal measure, the quahty of indomitable courage. Lord Erskine, however hard pressed, was no man to fear either the court or king or the king's judges, but he did his duty to his client in spite of all that power held out to intimidate or tempt him, and in spite of all opposition, even in those courts in which he practiced and of which he was the ornament and the pride. The same great qualities I have constantly observed in M. Berryer-that which is first of all the quality of an advocate - to reckon everything subordinate to the interests of his client-to have no purpose except to serve his cause effectively to make no deviation or digression to please either jury, or judge, or the populace, or the crown, but to do his duty looking only to the success of his client. And they who have not the matchless eloquence of these great men may worthily perform the rest of that duty, and may do it to their own honour, and infinitely to the advantage of their clients. In the administration of justice, the great advantage we have over all other nations is, that in this country its purity depends in the first place upon the purity of the judge, but in the next place upon the skill, the prudence, the discretion and the courage of the advocate. I see no worse fate that can befall this country than its losing the purity of its administration of justice-losing its certainty, and those other qualities which are the adniration of the world. I can conceive nothing more fatal to it than an infringement of the independence of the Bar; or a want of courage on the part of an advocate. As one of the most distinguished orators of the French Senate, our esteemed guest, M. Berryer, has always set hiniself against any attempt to interfere with the rights of the people, and it is his crowning glory that on every question the powers of his learning and eloquence have been fearlessly employed in defense of the liberties of his fellow citizens."

LoRd ChIEF Justice Cockburn: "We, who have had to pursue the study of jurisprudence with a view to its administration, know how much that noble science is indebted to the great and illustrious jurists of France, whose labors have shed so much light and lustre on that great profession. We, who have watched with interest the celebrated trials which, in our time, have occupied the tribunals of France, have been enabled to observe and appreciate the brilliant eloquence, the vast attainments, the great reasoning powers, the knowledge, the learning, the erudition, the courage, the energy and the independence of the Bar of that great country. We are happy to have this opportunity of paying the 
tribute of our respect to a Bar which is so eminent, and we rejoice exceedingly to find that that opportunity is afforded us at this celebration in the person of the most valued member, as well as the most efficient representative of the profession of which we are members, in a neighboring country. And allow me to say that, of all those intellectual qualities and attainments which distinguish the eminent and illustrious man whom we have this day met to honour, there is, in my mind, one virtue and one quality essential as the crowning virtue of every advocate - that of having conducted the functions of his great profession with unsullied and untarnished honour. My noble and learned friend, Lord Broughan, whose words are the words of wisdom, said that an advocate should be fearless in carrying out the interests of his client; but I couple that with this qualification and this restriction-that the arms which he wields are to be the arms of the warrior and not of the assassin. It is his duty to strive to accomphish the interest of his clients per fas, but not per nefas; it is his duty, to the utmost of his power, to seek to reconcile the interests he is bound to maintain, and the duty it is incumbent upon him to discharge, with the eternal and imnutable interests of truth and justice. ${ }^{2}$ In all the great causes he has been called upon to uphold, $M$. Berryer has never forgotten the gentleman and the man of honour, and I respect him as much for that as for the great and illustrious talents which have reflected so nuch honour upon his name and upon the profession of which he is such a distinguished ornament."

It would seem to be worth while to make accessible to American lawyers the foregoing full speeches, of which only summaries have heretofore been available, and to call especial attention to the footnote to Chief Justice Cockburn's speech, put there by Mr. Charles Pollock, "afterwards a Baron of the Exchequer," which shows that on the occasion of the dinner to M. Berryer, Lord Broughanı and Chief Justice Cockburn were fully agreed as to the moral obligations of advocacy.

$$
\text { George P. Costigan, Jr. }
$$

LONDON, ENGLAND,

JUNE 9, 1931.

2 Strong marks of assent from Lord Brougham followed the expression of this sentiment. 